\title{
THE EFFECT OF BIOSTIMULANTS DERIVED FROM VARIOUS MATERIALS ON THE YIELD AND SELECTED ORGANIC COMPONENTS OF ITALIAN RYE GRASS (LOLIUM MULTIFLORUM LAM.) AGAINST THE BACKGROUND OF NITROGEN REGIME
}

\author{
Ciepiela, G. A. - GodlewsKa, A.* \\ Institute of Health Sciences, Faculty of Natural Science, Siedlce University of Natural Sciences \\ and Humanities, B. Prusa 12 st., 08-110 Siedlce, Poland \\ (ORCID number: G. A. Ciepiela - 0000-0002-9235-3000; A. Godlewska - 0000-0003-1553-0867) \\ *Corresponding author \\ e-mail: godlewskaa@uph.edu.pl
}

(Received $9^{\text {th }}$ May 2019; accepted $16^{\text {th }}$ Jul 2019)

\begin{abstract}
The present work is an attempt to assess the effect of biostimulants derived from various materials on the yield and selected organic components in Italian rye grass against the background of nitrogen regime. A field experiment was arranged as a randomized subblock design (split-plot) in Poland in August 2013. The following factors were examined: type of biostimulant: Algex, Tytanit, Asahi SL and a control (no biostimulant addition); and nitrogen application rate: 0 (control); 120 and $180 \mathrm{~kg} \mathrm{ha}^{-1}$. The results reported here indicate that biostimulants applied in the study contributed to similar yield performance to plants fertilised with a $60 \mathrm{~kg} \mathrm{ha}^{-1}$ lower nitrogen rate, the highest increase in yield (42.2\%) being recorded for Algex-treated grass. An application of biostimulants beneficially affected Italian rye grass yield quality as it was followed by a significant increase in chlorophyll content in leaves as well as protein compounds and soluble carbohydrates in the dry matter of the test grass. The nitrogen rate of 120 and $180 \mathrm{~kg} \mathrm{ha}^{-1}$ significantly increased Italian rye grass yields, chlorophyll content in plant leaves and protein compounds, the concentration of soluble carbohydrates being significantly lower in the dry matter of test plants.
\end{abstract}

Keywords: grass, fertilisation, chlorophyll, protein compounds, soluble carbohydrates

\section{Introduction}

Agriculture intensification has undoubtedly contributed to an increase in the effectiveness and efficiency of crop and animal production. Simultaneously, such farming relying on an application of high rates of mineral fertiliser and plant protection agents negatively influences soil effectiveness (Reguraman et al., 2019), and the quality of the final products. Moreover, it leads to natural environment degradation. In recent years, there has been an increase in the plant growth and frequency development regulator use frequency in crop production, also called biostimulants, in order to counteract intensive fertilisation, nitrogen application in particular. The products contain biologically active substances which affect metabolism and so make it possible to obtain higher plant efficiency (Kocira et al., 2015). On their own, biostimulants are not nutritional products but they increase nutrient uptake from soil (Brown and Saa, 2015). Growth stimulants are of either mineral or organic origins (Kocira et al., 2016) and are produced from algae and seaweed extracts (Algex), microorganisms, phytohormones as well as macro- and microelements (Tytanit, Asahi). An application of these products is safe for the environment (Tuhy et al., 2013) and may partly complement the influence of crop plant production chemicals, including mineral 
fertilisation (Murawska et al., 2017). Relevant literature on the subject has demonstrated that individual biostimulants may have a different effect on yield quality and quantity, an increase in nutrient availability for plants, water retention ability, antioxidant content and chlorophyll production in plants (Khan et al., 2009; Sharma et al., 2014; Godlewska and Ciepiela, 2016a). Growth stimulants affect synthesis of natural plant hormones and an increase in their activity. According to research reports (Haider et al., 2012; Renuka et al., 2018), biostimulant application can also reduce abiotic and biotic stress of crop plants. Research has confirmed a positive effect of this type of products on crop plants, but it has also demonstrated that their effect is more dependent on crop plant species and cultivar than biostimulant rate (Sultana et al., 2005). Growth regulators are applied worldwide in vegetable and fruit production as well as cereals, oil seed rape and maize. However, there is still a paucity of reports on the efficiency of these products applied to fodder grasses constituting grassland established on ploughed land. Thus, the authors of the present work attempted to assess the effect of biostimulants derived from various materials on the yielding, chlorophyll content, protein content and simple sugars in Lolium multiflorum against the background of nitrogen regime.

\section{Materials and methods}

A field experiment was arranged as a randomized subblock design (split-plot) with three replicates at the Siedlce Experimental Unit of the University of Natural Sciences and Humanities in Poland $\left(52.169^{\circ} \mathrm{N}, 22.280^{\circ} \mathrm{E}\right)$ in the second decade of August 2013. The plot area was $10 \mathrm{~m}^{2}$. According to the Polish soil classification system (Systematics of Polish Soils, 2011), the soil used in the experiment was the culture soils with the hortisole type, developed from loamy sand. Based on the analysis performed at the Regional Chemical Station in Wesoła (Table 1). The following factors were examined:

- Type of biostimulant: Algex, Tytanit, Asahi SL and a control (no biostimulant addition)

- Nitrogen application rate: 0 (control); 120 and $180 \mathrm{~kg} \cdot \mathrm{ha}^{-1}$

Table 1. The chemical composition of soil

\begin{tabular}{|c|c|c|c|c|c|}
\hline \multirow{3}{*}{$\begin{array}{c}\mathrm{pH} \\
\text { in } 1 \mathrm{n} \mathrm{KCL}\end{array}$} & \multicolumn{5}{|c|}{ Content of soil } \\
\hline & \multirow{2}{*}{ Humus (\%) } & \multicolumn{3}{|c|}{ Assimilable components ( $\mathrm{mg} \mathrm{kg}^{-1}$ of soil) } & \multirow{2}{*}{$\begin{array}{c}\mathrm{N}-\text { total } \\
\left(\mathrm{g} \mathrm{kg}^{-1} \text { d.m. soil }\right) \\
\end{array}$} \\
\hline & & $\mathbf{P}_{2} \mathbf{O}_{4}^{-}$ & $\mathbf{K}^{+}$ & $\mathrm{Mg}^{2+}$ & \\
\hline 6.8 & 3.78 & 170 & 114 & 84 & 1.3 \\
\hline
\end{tabular}

Algex is an extract of the sea alga Ascophyllum nodosum which contains vitamins, amino acids, phytohormones (auxins, cytokinins, gibberellins), polysaccharides, betaine as well as macro- and microelements such as $\mathrm{N}-8 \%, \mathrm{P}-3.6 \%, \mathrm{~K}-7 \%, \mathrm{~B}-0.036 \%$, $\mathrm{Zn}-0.025 \%, \mathrm{Cu}-0.009 \%, \mathrm{Fe}-0.016 \%, \mathrm{Mn}-0.036 \%$ and $\mathrm{Mo}-0.0036 \%$. Algex is manufactured by Rosier, Moustier, Belgium.

Tytanit is produced by INTERMAG Ltd., Olkusz, Poland. Tytanit contains $8.5 \mathrm{~g}$ Ti per $1 \mathrm{dm}^{3}(0.8 \% \mathrm{~m} / \mathrm{m})$ in the form of Ti-ascorbate.

Asahi SL is produced by Arysta Life Science Ltd., Warsaw, Poland. The product contains the following phenolic compounds: sodium p-nitrophenolate $-0.3 \%$, sodium o-nitrophenolate $-0.2 \%$ and sodium 5-nitroguaiacolate $-0.1 \%$. 
The sowing rate of Lolium multiflorum Lam. cv. Dukat was calculated based on the standards drawn up by IMUZ (the Institute for Land Reclamation and Grassland Farming) (Jankowski et al., 2005). Standard cultivation methods were applied in the experiment and, additionally, plants were fertilised with different biostimulants.

The grass sowing rate was $31 \mathrm{~kg} \mathrm{ha}^{-1}$ (TWG - thousand-grain weight $-2.8 \mathrm{~g}$, 11071429 kernels per hectare). In 2013, when seeds were sown, neither biostimulants nor nitrogen fertiliser was applied. In October 2013 only one cut was performed at the plant height of $6 \mathrm{~cm}$. Over the study period (2014-2015), the cutting regime consisted of three harvests per year. Ammonium nitrate was applied three times per year. The total nitrogen amount was split into three equal rates which were applied before each cutting. $\mathrm{P}$ and $\mathrm{K}$ fertilisation was applied to all the plots. Phosphorus was applied once as triple superphosphate at the rate of $40 \mathrm{~kg} \mathrm{ha}^{-1} \mathrm{P}_{2} \mathrm{O}_{5}$ in the spring. The amount of potassium $\left(160 \mathrm{~kg} \mathrm{ha}^{-1} \mathrm{~K}_{2} \mathrm{O}\right)$ was split into three equal rates and applied prior to each cutting as $60 \%$ potash salt. The biostimulants was sprayed as an aqueous solution. The spraying was performed before each cutting: the first application was three weeks before the first cutting, the second one two weeks after the first harvest and the last one three weeks after the second harvest. Biostimulant rates following each cut were applied as recommended by the manufacturer, that is thinned with water to obtain the volume of $400 \mathrm{dm}^{3}$ : Algex $-6 \mathrm{dm}^{3} \mathrm{ha}^{-1}$, Tytanit $-0.4 \mathrm{dm}^{3} \mathrm{ha}^{-1}$, Asahi SL $-0.6 \mathrm{dm}^{3} \mathrm{ha}^{-1}$.

Leaf chlorophyll was determined using a Minolta Chlorophyll Meter SPAD-502. It measures the light absorption by leaves at the wavelength of 650 and $940 \mathrm{~nm}$. The quotients of light absorption at the two wavelengths are unitless and are called SPAD values. They reflect the leaf greenness index which corresponds to the total chlorophyll content (Blackmer and Schepers, 1994). Measurements were taken in each plot on 10 randomly selected grass leaves (top leaves) the day before harvest.

During harvest of each cut, green matter from each plot (whole area, that is $10 \mathrm{~m}^{2}$ ) was weighed to determine the yield, and $0.5 \mathrm{~kg}$ green matter samples of grass were taken to determine the drying-up coefficient and to carry out chemical analyses. The samples were left to dry in a ventilated room. Airy dry matter was weighed (to determine dry matter yield per plot) and was then shredded and ground. The obtained material was subjected to chemical analysis to determine dry matter (by determining moisture content), protein compounds, and soluble carbohydrates. The method of determination was near-infrared spectroscopy (NIRS) using a NIRFlex N-500 spectrometer and ready-to-use INGOT calibration applications.

Statistical analysis was conducted using the program STATISTICA StatSoft, Inc. (2011), STATISTICA (data analysis software system), version 10 (www.statsoft.com). Significance of differences between means was checked using the Tukey test at the significance level of $\alpha \leq 0.05$.

Meteorological conditions during the study period were changeable and precipitation was very unevenly distributed (Table 2). The mean air temperature in the 2015 growing season was by 2 degrees lower than the mean across 2006-2015. By contract, unusual precipitation shortages occurred in September 2014, April and August 2015.

\section{Results and discussion}

The results of the research demonstrated that all the biostimulants affected Italian rye grass yielding. Regardless of the study years and nitrogen rate (Table 3), significantly higher grass biomass yields were determined following an application of biostimulants 
compared with control yields of grass dry matter. Algex, Tytanit and Asahi contributed to an increase in biomass yield, respectively by $42.2,27.3$ and $18.8 \%$, on average, compared with control yields. An application of Tytanit and Asahi significantly increased plant dry matter yields compared with control (where no biostimulants had been used). However, in each study year and for all the nitrogen rates biomass yields of plants treated with these biostimulants were significantly lower compared with biomass yields harvested in Algex-treated plots. Many authors have confirmed a positive effect of these biostimulants on yield amount for various crop plants (Nerrisa et al., 2016; Godlewska and Ciepiela, 2016b; Kovacik et al., 2018; Whitted-Haag et al., 2014; Przybysz et al., 2014). However, Lola-Luz et al. (2013) reported different results of their studies. Following an application of Ascophyllum nodosum extract, they found no statistical increase in cabbage yield. Thus, it should be noted that the effect of biostimulants may be highly influenced by crop plant species (Michałek et al., 2018) and further investigation of this issue is warranted.

Italian rye grass is a short-lived species as have been demonstrated by results of this research. In the first study year, yields of this grass species were by $49.6 \%$ higher compared with the second year, the differences being statistically significant.

Nitrogen regime significantly increased yields of the grass. In both the study years, increasing nitrogen fertiliser rates contributed to a significant increase in Italian rye grass yields compared with control where no nitrogen had been applied. The highest increase in Italian rye grass yield (by 73.9\%), compared with control, was recorded in the second study year after the rate of $180 \mathrm{~kg} \mathrm{~N} \mathrm{ha}^{-1}$ had been applied.

An increase in nitrogen rate was followed by a significant increase in the dry matter of the grass in the control unit and the biostimulant-treated plots.

Dry matter yields $\left(\mathrm{t} \mathrm{ha}^{-1}\right)$ for individual cuts as affected by nitrogen regime and biostimulant type are shown in Table 4. Regardless of the remaining factors, the highest Italian rye grass biomass yields were harvested with the second cut, which may have been associated with meteorological conditions (Table 2). The yields differed significantly from those harvested with the first and third cut.

Table 2. Meteorological condition in years 2014-2015 by meteorological station in Siedlce

\begin{tabular}{|c|c|c|c|c|c|c|c|}
\hline \multirow{3}{*}{ Years } & \multicolumn{6}{|c|}{ Means monthly air temperatures $\left({ }^{\circ} \mathbf{C}\right)$} & \multirow{3}{*}{$\begin{array}{c}\text { Means in } \\
\text { growing season } \\
\left(\text { IV-IX) }\left({ }^{\circ} \mathrm{C}\right)\right.\end{array}$} \\
\hline & \multicolumn{6}{|c|}{ Month } & \\
\hline & IV & $\mathbf{V}$ & VI & VII & VIII & IX & \\
\hline 2014 & 9.7 & 13.7 & 15.1 & 20.4 & 17.8 & 13.7 & 15.1 \\
\hline 2015 & 8.1 & 12.3 & 16.5 & 14.3 & 21.1 & 8.8 & 13.5 \\
\hline $\begin{array}{c}\text { Mean of many } \\
\text { years } \\
(2006-2015)\end{array}$ & 9.6 & 14.0 & 17.2 & 19.9 & 18.4 & 13.6 & 15.5 \\
\hline \multirow{3}{*}{ Years } & \multicolumn{6}{|c|}{ Monthly precipitation (mm) } & \multirow{3}{*}{$\begin{array}{c}\text { Sum in season } \\
(\mathrm{IV}-\mathrm{IX})(\mathrm{mm})\end{array}$} \\
\hline & \multicolumn{6}{|c|}{ Month } & \\
\hline & IV & $\mathbf{V}$ & VI & VII & VIII & $\mathbf{I X}$ & \\
\hline 2014 & 39.5 & 79.3 & 50.3 & 62.5 & 66.3 & 26.7 & 324.6 \\
\hline 2015 & 29.7 & 100.6 & 41.1 & 68.3 & 12.0 & 77.5 & 329.2 \\
\hline $\begin{array}{c}\text { Mean of many } \\
\text { years } \\
(2006-2015)\end{array}$ & 26.9 & 68.9 & 64.6 & 55.8 & 65.3 & 44.3 & 325.8 \\
\hline
\end{tabular}


Table 3. Dry matter yield of Italian rye grass $\left(t \mathrm{ha}^{-1}\right)$ (sum of three cuts)

\begin{tabular}{|c|c|c|c|c|c|c|}
\hline \multirow[b]{2}{*}{ Year } & \multirow[b]{2}{*}{$\begin{array}{c}\text { Dose of N } \\
\text { kg ha }^{-1}\end{array}$} & \multicolumn{4}{|c|}{ Biostimulant } & \multirow[b]{2}{*}{ Mean } \\
\hline & & \begin{tabular}{|c|}
$\begin{array}{c}\text { Without } \\
\text { biostimulant } \\
\text { (control) }\end{array}$ \\
\end{tabular} & Algex & Tytanit & Asahi SL & \\
\hline \multirow{3}{*}{2014} & 0 & A $12.6 \mathrm{a}$ & A $17.7 \mathrm{~b}$ & A $15.8 \mathrm{c}$ & A $14.5 \mathrm{~d}$ & $15.2 \mathrm{~A}$ \\
\hline & 120 & B $17.4 \mathrm{a}$ & B 22.4 b & B 20.2 c & B $18.7 \mathrm{~d}$ & $19.7 \mathrm{~B}$ \\
\hline & 180 & C $19.0 \mathrm{a}$ & $\mathrm{C} 23.3 \mathrm{~b}$ & $\mathrm{C} 22.2 \mathrm{c}$ & $\mathrm{C} 20.7 \mathrm{~d}$ & $21.3 \mathrm{C}$ \\
\hline \multirow{3}{*}{2015} & 0 & A $5.6 \mathrm{a}$ & A 10.8 b & A $9.7 \mathrm{c}$ & A $9.1 \mathrm{c}$ & $8.8 \mathrm{~A}$ \\
\hline & 120 & B 9.9 a & B $15.8 \mathrm{~b}$ & B $14.4 \mathrm{c}$ & B $13.7 \mathrm{c}$ & $13.5 \mathrm{~B}$ \\
\hline & 180 & $\mathrm{C} 12.4 \mathrm{a}$ & $\mathrm{C} 18.9 \mathrm{~b}$ & $\mathrm{C} 15.4 \mathrm{c}$ & $\mathrm{C} 14.6 \mathrm{c}$ & $15.3 \mathrm{C}$ \\
\hline 2014 & \multirow{2}{*}{ Mean } & A $16.3 \mathrm{a}$ & A $21.1 \mathrm{~b}$ & A $19.4 \mathrm{c}$ & A $18.0 \mathrm{c}$ & $18.7 \mathrm{~A}$ \\
\hline 2015 & & B $9.3 \mathrm{a}$ & B $15.2 \mathrm{~b}$ & B $13.2 \mathrm{c}$ & $\mathrm{B} 12.5 \mathrm{c}$ & $12.5 \mathrm{~B}$ \\
\hline \multirow{3}{*}{ Mean } & 0 & A $9.1 \mathrm{a}$ & A 14.3 b & A $12.8 \mathrm{c}$ & A $11.8 \mathrm{c}$ & $12.0 \mathrm{~A}$ \\
\hline & 120 & B $13.7 \mathrm{a}$ & B $19.1 \mathrm{~b}$ & B $17.3 \mathrm{c}$ & B $16.2 \mathrm{c}$ & $16.6 \mathrm{~B}$ \\
\hline & 180 & C $15.7 \mathrm{a}$ & $\mathrm{C} 21.1 \mathrm{~b}$ & $\mathrm{C} 18.8 \mathrm{c}$ & C $17.7 \mathrm{c}$ & $18.3 \mathrm{C}$ \\
\hline \multicolumn{2}{|c|}{ Mean } & $12.8 \mathrm{a}$ & $18.2 \mathrm{~b}$ & $16.3 \mathrm{c}$ & $15.2 \mathrm{c}$ & 15.6 \\
\hline
\end{tabular}

Different lower-case letters within the same line indicate significant differences. Different uppercase letters indicate that the values in the column for individual factors (Dose $\mathrm{N}$ and Year) and their interaction differ significantly

Table 4. The effect of the biostimulants on dry matter yield of Italian rye grass by cut and nitrogen fertilization ( $t \mathrm{ha}^{-1}$ ) (mean of two years)

\begin{tabular}{|c|c|c|c|c|c|c|}
\hline \multirow[b]{2}{*}{ Cut } & \multirow[b]{2}{*}{$\begin{array}{c}\text { Dose of N } \\
\text { kg ha }^{-1}\end{array}$} & \multicolumn{4}{|c|}{ Biostimulant } & \multirow[b]{2}{*}{ Mean } \\
\hline & & $\begin{array}{c}\text { Without } \\
\text { biostimulant } \\
\text { (control) }\end{array}$ & Algex & Tytanit & Asahi SL & \\
\hline \multirow{3}{*}{1} & 0 & A $2.6 \mathrm{a}$ & A $3.2 \mathrm{~b}$ & A $3.0 \mathrm{ab}$ & A $2.9 \mathrm{ab}$ & $2.9 \mathrm{~A}$ \\
\hline & 120 & B $4.2 \mathrm{a}$ & B 5.4 b & B 5.3 b & B $4.6 \mathrm{ac}$ & $4.9 \mathrm{~B}$ \\
\hline & 180 & B $4.3 \mathrm{a}$ & $\mathrm{C} 6.7 \mathrm{~b}$ & B 5.7 c & C $5.3 \mathrm{c}$ & $5.5 \mathrm{C}$ \\
\hline \multirow{3}{*}{2} & 0 & A $4.3 \mathrm{a}$ & A $6.6 \mathrm{~b}$ & A 5.9 c & A $5.4 \mathrm{~d}$ & $5.6 \mathrm{~A}$ \\
\hline & 120 & B $6.3 \mathrm{a}$ & B $8.6 \mathrm{~b}$ & B $7.7 \mathrm{c}$ & B $7.4 \mathrm{c}$ & $7.5 \mathrm{~B}$ \\
\hline & 180 & C $7.1 \mathrm{a}$ & B 8.9 b & C $8.3 \mathrm{c}$ & C $8.0 \mathrm{c}$ & $8.1 \mathrm{C}$ \\
\hline \multirow{3}{*}{3} & 0 & A $2.3 \mathrm{a}$ & A 4.4 b & A 3.9 c & A $3.5 \mathrm{c}$ & $3.5 \mathrm{~A}$ \\
\hline & 120 & B $3.2 \mathrm{a}$ & B $5.0 \mathrm{~b}$ & $\mathrm{AB} 4.4 \mathrm{c}$ & B $4.2 \mathrm{c}$ & $4.2 \mathrm{~B}$ \\
\hline & 180 & C $4.3 \mathrm{a}$ & C $5.6 \mathrm{~b}$ & B 4.9 c & B $4.4 \mathrm{a}$ & $4.8 \mathrm{C}$ \\
\hline 1 & \multirow{3}{*}{ Mean } & A 3.7 a & A $5.1 \mathrm{~b}$ & A $4.7 b c$ & A $4.3 \mathrm{c}$ & $4.4 \mathrm{~A}$ \\
\hline 2 & & B 5.9 a & B $8.0 \mathrm{~b}$ & B $7.3 \mathrm{c}$ & B 6.9 c & $7.0 \mathrm{~B}$ \\
\hline 3 & & A $3.3 \mathrm{a}$ & A $5.0 \mathrm{~b}$ & A $4.4 \mathrm{c}$ & A $4.0 \mathrm{c}$ & $4.2 \mathrm{~A}$ \\
\hline \multirow{3}{*}{ Mean } & 0 & A $3.1 \mathrm{a}$ & A $4.7 \mathrm{~b}$ & A $4.3 \mathrm{bc}$ & A 3.9 c & $4.0 \mathrm{~A}$ \\
\hline & 120 & B 4.6 a & B $6.3 \mathrm{~b}$ & B 5.8 c & B $5.4 \mathrm{c}$ & $5.5 \mathrm{~B}$ \\
\hline & 180 & C $5.2 \mathrm{a}$ & C $7.1 \mathrm{~b}$ & B 6.3 c & B 5.9 c & $6.1 \mathrm{C}$ \\
\hline \multicolumn{2}{|c|}{ Mean } & $4.3 \mathrm{a}$ & $6.1 \mathrm{~b}$ & $5.4 \mathrm{c}$ & $5.1 \mathrm{c}$ & 5.2 \\
\hline
\end{tabular}

Different lower-case letters within the same line indicate significant differences. Different uppercase letters indicate that the values in the column for individual factors (Dose $\mathrm{N}$ and Cut) and their interaction differ significantly 
Regardless of nitrogen regime, biostimulants significantly increased Italian rye grass yields. Moreover, compared with control, higher dry matter yields were recorded for Tytanit-treated plants harvested with the first cut in units without nitrogen fertilisation, and Asahi-sprayed grass harvested in plots without nitrogen fertilisation and fertilised with $120 \mathrm{~kg} \mathrm{~N} \mathrm{ha}^{-1}$, the differences being statistically insignificant. It should be mentioned that, following an application of biostimulants, similar yields were produced at a lower (by $60 \mathrm{~kg} \mathrm{ha}^{-1}$ ) nitrogen rate.

Nitrogen fertilisation at the rate of 120 and $180 \mathrm{~kg} \mathrm{ha}^{-1}$ resulted in a significant increase in Italian rye grass yields harvested with all the cuts compared with the biomass of the non-fertilised control.

Increased nitrogen rates contributed to an increase in the dry matter yield of Italian ryegrass in all the plots treated with the biostimulants and in the control unit although not all the differences were statistically significant.

Chlorophyll content in Italian rye grass leaves harvested with individual cuts as affected by nitrogen regime and biostimulant application is presented in Table 5. Regardless of biostimulant use and nitrogen fertilisation, chlorophyll content in the leaves of the test grass fluctuated significantly during the growing season. Chlorophyll content was the lowest in the leaves of grass harvested with the first cut, it being the highest in the leaves of plants harvested with the third cut. Similar results were reported by Ciepiela and Godlewska (2015).

Table 5. The effect of the biostimulants on content of chlorophyll in leaves of Italian rye grass (value of SPAD) by cut and nitrogen fertilization (mean of two years)

\begin{tabular}{|c|c|c|c|c|c|c|}
\hline \multirow[b]{2}{*}{ Cut } & \multirow[b]{2}{*}{$\begin{array}{c}\text { Dose of } N \\
\text { kg ha }^{-1}\end{array}$} & \multicolumn{4}{|c|}{ Biostimulant } & \multirow[b]{2}{*}{ Mean } \\
\hline & & $\begin{array}{c}\text { Without } \\
\text { biostimulant } \\
\text { (control) }\end{array}$ & Algex & Tytanit & Asahi SL & \\
\hline \multirow{3}{*}{1} & 0 & A $35.0 \mathrm{a}$ & A $36.5 \mathrm{ab}$ & A $38.1 \mathrm{~b}$ & A 40.9 bc & $37.6 \mathrm{~A}$ \\
\hline & 120 & A 34.9 a & A $36.7 \mathrm{ab}$ & A 38.6 b & A $42.3 \mathrm{c}$ & $38.1 \mathrm{~A}$ \\
\hline & 180 & A 32.6 a & A $35.6 \mathrm{a}$ & B $41.8 \mathrm{~b}$ & B $43.8 \mathrm{~b}$ & $38.5 \mathrm{~A}$ \\
\hline \multirow{3}{*}{2} & 0 & A $34.2 \mathrm{a}$ & A $35.0 \mathrm{a}$ & A $40.1 \mathrm{~b}$ & A $42.9 \mathrm{c}$ & $38.1 \mathrm{~A}$ \\
\hline & 120 & A 33.9 a & B $40.0 \mathrm{~b}$ & A $40.1 \mathrm{bc}$ & B $46.1 \mathrm{~d}$ & $40.0 \mathrm{~B}$ \\
\hline & 180 & B $41.1 \mathrm{a}$ & $\mathrm{C} 42.2 \mathrm{ab}$ & B $43.9 \mathrm{~b}$ & B 44.7 bc & $43.0 \mathrm{C}$ \\
\hline \multirow{3}{*}{3} & 0 & A $36.7 \mathrm{a}$ & A $38.4 \mathrm{a}$ & A 40.2 b & A $42.6 \mathrm{c}$ & $39.5 \mathrm{~A}$ \\
\hline & 120 & B $38.5 \mathrm{a}$ & A $39.7 \mathrm{a}$ & B $45.7 \mathrm{~b}$ & B $47.6 \mathrm{c}$ & $42.9 \mathrm{~B}$ \\
\hline & 180 & B $38.8 \mathrm{a}$ & B $42.4 \mathrm{~b}$ & B $45.2 \mathrm{c}$ & B $46.1 \mathrm{c}$ & $43.1 \mathrm{~B}$ \\
\hline \multirow{3}{*}{ Mean } & 0 & A $35.3 \mathrm{a}$ & A $36.6 \mathrm{a}$ & A 39.5 b & A $42.1 \mathrm{c}$ & $38.4 \mathrm{~A}$ \\
\hline & 120 & A 35.8 a & B 38.8 b & B 41.5 c & B $45.3 \mathrm{~d}$ & $40.3 \mathrm{~B}$ \\
\hline & 180 & B $37.5 \mathrm{a}$ & B $40.1 \mathrm{~b}$ & C $43.6 \mathrm{c}$ & B $45.0 \mathrm{~d}$ & $41.5 \mathrm{~B}$ \\
\hline 1 & \multirow{3}{*}{ Mean } & A $34.2 \mathrm{a}$ & A $36.3 \mathrm{a}$ & A 39.5 b & A $42.3 \mathrm{c}$ & $38.1 \mathrm{~A}$ \\
\hline 2 & & B $36.4 \mathrm{a}$ & B $39.1 \mathrm{~b}$ & B $41.4 \mathrm{c}$ & B $44.6 \mathrm{~d}$ & $40.4 \mathrm{~B}$ \\
\hline 3 & & C $38.0 \mathrm{a}$ & B $40.2 \mathrm{~b}$ & C $43.7 \mathrm{c}$ & B $45.4 \mathrm{~d}$ & $41.8 \mathrm{C}$ \\
\hline \multicolumn{2}{|c|}{ Mean } & $36.2 \mathrm{a}$ & $38.5 \mathrm{~b}$ & $41.5 \mathrm{c}$ & $44.1 \mathrm{~d}$ & 40.1 \\
\hline
\end{tabular}

Different lower-case letters within the same line indicate significant differences. Different uppercase letters indicate that the values in the column for individual factors (Dose $\mathrm{N}$ and Cut) and their interaction differ significantly 
Regardless of the remaining factors, all the biostimulants applied in the experiment contributed to a significant increase in chlorophyll content in Italian rye grass leaves although their effect was not the same. Tytanit and Asahi significantly increased (by 14.6 and $21.8 \%$, respectively) chlorophyll content in plant leaves compared with control grass which had not been treated with the biostimulants. A positive effect of biostimulants on chlorophyll amount in leaves has been confirmed by Kováčik et al. (2018), Radkowski (2013) who applied Tytanit, as well as by Borowski and Blamowski (2009) and Przybysz et al. (2014) who used Atonik (equivalent of Asahi). An application of Algex was also associated with an increase in chlorophyll content in grass leaves but the increase was barely $6.4 \%$ compared with control and it was insignificant. El-Miniawy et al. (2014) applied Algreen and observed an increase in chlorophyll content in strawberry leaves whereas Pacheco et al. (2019), who applied Ascophyllum nodosum extract, observed lower chlorophyll contents in Achilleamille folium L. leaves.

Analysis of the average chlorophyll content in Italian rye grass leaves revealed that the rate of 120 and $180 \mathrm{~kg} \mathrm{~N} \mathrm{ha}^{-1}$ resulted in a significant increase in the amount of this pigment in the test grass leaves. Distribution of chlorophyll content in the leaves of plants harvested with individual cuts indicated that nitrogen regime had no significant effect on the characteristic tested for plants harvested with the first cut.

Increasing nitrogen rates significantly affected chlorophyll content in Italian ryegrass harvested in units treated with Tytanit. In the remaining plots, an increase in nitrogen rate contributed to an increase in chlorophyll content in the grass although the majority of the differences were statistically insignificant.

The concentration of protein compounds in the dry matter of Italian rye grass averaged $106.4 \mathrm{~g} \mathrm{~kg}^{-1} \mathrm{DM}$ (Table 6 ) and was influenced by all the experimental factors. Regardless of the nitrogen regime and biostimulant application, the lowest amount of protein compounds was determined in grass harvested with the first cut, and the highest in the third cut, the differences being statistically significant.

Biostimulants tend to increase certain contents, for example protein content or sugars, affecting yield quality (Aydin et al., 2012; Kocira et al., 2017). In the study reported here, the average highest increase in the plant content of protein compounds following an application of Tytanit was $27.5 \%$ compared with control. Both Tytanit and Asahi significantly increased protein compounds in the dry matter of Italian rye grass harvested with all the cuts at each nitrogen rate. Also Algex had a positive effect on the amount of protein compounds in the test grass but the effect of an application of the biostimulant was frequently dependent on the cut and nitrogen rate. An application of this biostimulant resulted in a significant increase in protein compounds determined in grass harvested with the first and second cut in plots without nitrogen fertilisation, and with the third cut at all the nitrogen rates. There are research papers published worldwide which have confirmed a positive effect of the above-mentioned biostimulants on protein compounds in crop plants (Haroun et al., 2011; Ciepiela and Godlewska, 2015; Murawska et al., 2017; Hidangmayum and Sharma, 2017).

Nitrogen fertilisation significantly increased protein compounds in Italian rye grass dry matter. Their amount in plants harvested with all the cuts increased as increasing nitrogen rates were applied, the differences being statistically significant. Nitrogen applied at the rate of 120 and $180 \mathrm{~kg} \mathrm{ha}^{-1}$ contributed to an increase in the dry matter content of protein compounds, the respective increases being 22.1 and $43.1 \%$, compared with plants harvested in plots where no nitrogen had been applied. 
Table 6. The effect of the biostimulants on content of protein compounds in Italian rye grass by cut and nitrogen fertilization ( $\left.\mathrm{g} \mathrm{kg}^{-1} \mathrm{DM}\right)$ (mean of two years)

\begin{tabular}{|c|c|c|c|c|c|c|}
\hline \multirow[b]{2}{*}{ Cut } & \multirow[b]{2}{*}{$\begin{array}{c}\text { Dose of N } \\
\mathrm{kg} \mathrm{ha}^{-1}\end{array}$} & \multicolumn{4}{|c|}{ Biostimulant } & \multirow[b]{2}{*}{ Mean } \\
\hline & & $\begin{array}{c}\text { Without } \\
\text { biostimulant } \\
\text { (control) }\end{array}$ & Algex & Tytanit & Asahi SL & \\
\hline \multirow{3}{*}{1} & 0 & A 59.2 a & A $91.7 \mathrm{~b}$ & A $79.2 \mathrm{c}$ & A $76.1 \mathrm{c}$ & $76.6 \mathrm{~A}$ \\
\hline & 120 & B $83.2 \mathrm{a}$ & A 89.7 ac & B $124.0 \mathrm{~b}$ & B $94.1 \mathrm{c}$ & $97.8 \mathrm{~B}$ \\
\hline & 180 & C 108.9 a & B $116.6 \mathrm{ab}$ & B $123.4 \mathrm{~b}$ & C $127.8 \mathrm{bc}$ & $119.2 \mathrm{C}$ \\
\hline \multirow{3}{*}{2} & 0 & A $63.6 \mathrm{a}$ & A 112.4 b & A 86.9 c & A $77.3 \mathrm{~d}$ & $85.1 \mathrm{~A}$ \\
\hline & 120 & B 90.2 a & B $94.4 \mathrm{a}$ & B $127.6 \mathrm{~b}$ & B 103.7 c & $104.0 \mathrm{~B}$ \\
\hline & 180 & C $106.7 \mathrm{a}$ & A $112.1 \mathrm{ab}$ & C $115.4 \mathrm{~b}$ & C $141.1 \mathrm{c}$ & $118.8 \mathrm{C}$ \\
\hline \multirow{3}{*}{3} & 0 & A 66.4 a & A 129.8 b & A $107.1 \mathrm{c}$ & A $98.8 \mathrm{~d}$ & $100.5 \mathrm{~A}$ \\
\hline & 120 & B 106.6 a & B $113.3 \mathrm{~b}$ & B $136.0 \mathrm{c}$ & B $117.2 \mathrm{bd}$ & $118.3 \mathrm{~B}$ \\
\hline & 180 & C 126.6 a & A $132.6 \mathrm{~b}$ & B $135.8 \mathrm{bc}$ & C $154.1 \mathrm{~d}$ & $137.3 \mathrm{C}$ \\
\hline \multirow{3}{*}{ Mean } & 0 & A $63.1 \mathrm{a}$ & A $111.3 \mathrm{~b}$ & A $91.1 \mathrm{c}$ & A $84.1 \mathrm{c}$ & $87.4 \mathrm{~A}$ \\
\hline & 120 & B 93.3 a & B $99.1 \mathrm{ac}$ & B 129.2 b & B 105.0 c & 106.7 B \\
\hline & 180 & C $114.1 \mathrm{a}$ & C $120.4 \mathrm{~b}$ & B $124.9 \mathrm{~b}$ & C $141.0 \mathrm{c}$ & $125.1 \mathrm{C}$ \\
\hline 1 & \multirow{3}{*}{ Mean } & A 83.8 a & A $99.3 \mathrm{~b}$ & A $108.9 \mathrm{~b}$ & A 99.3 b & $97.8 \mathrm{~A}$ \\
\hline 2 & & A 86.8 a & A 106.3 b & A $110.0 \mathrm{~b}$ & A 107.4 b & $102.6 \mathrm{~A}$ \\
\hline 3 & & В 99.9 a & B $125.2 \mathrm{~b}$ & B 126.3 b & B $123.4 \mathrm{~b}$ & $118.7 \mathrm{~B}$ \\
\hline \multicolumn{2}{|c|}{ Mean } & $90.2 \mathrm{a}$ & $110.3 b c$ & $115.0 \mathrm{~b}$ & $110.0 \mathrm{c}$ & 106.4 \\
\hline
\end{tabular}

Different lower-case letters within the same line indicate significant differences. Different uppercase letters indicate that the values in the column for individual factors (Dose $\mathrm{N}$ and Cut) and their interaction differ significantly

An increase in nitrogen rate was followed by a significant increase in protein content in Italian ryegrass grown in units which were either without biostimulant or treated with Algex or Asahi SL.

Soluble carbohydrates in Italian rye grass were affected by cuts, an application of biostimulants and nitrogen regime (Table 7). Regardless of the experimental factors, the average concentration of these compounds in dry matter was $123.7 \mathrm{~g} \mathrm{~kg}^{-1}$. The highest concentration of soluble carbohydrates was determined in the grass of the cut harvested in spring, which may have been due to a substantial utilisation of these compounds because of increased plant respiration at high temperatures (the second and third cut) which makes use of sugars. Similar findings were reported in previous works which examined a biostimulant produced from brown algae applied to Dactylis glomerata and Festulolium braunii (Ciepiela and Godlewska, 2014).

Regardless of the cuts and nitrogen regime, all the biostimulants applied in the experiment significantly increased soluble carbohydrates in Italian rye grass compared with control plants (by 35.2\%, on average). A positive effect of extracts obtained from sea algae on the concentration of soluble carbohydrates in plants has been reported by other authors, too (Zodape et al., 2010; Haroun et al., 2011). However, not all studies have confirmed the above tendencies. Cwalina-Ambroziak and Amarowicz (2012) applied Asahi SL and observed a decline in the sugar content of tomato and red pepper fruit. 
Table 7. The effect of the biostimulants on content of soluble carbohydrates in Italian rye grass by cut and nitrogen fertilization $\left(\mathrm{g} \mathrm{kg}^{-1} \mathrm{DM}\right)$ (mean of two years)

\begin{tabular}{|c|c|c|c|c|c|c|}
\hline \multirow[b]{2}{*}{ Cut } & \multirow[b]{2}{*}{$\begin{array}{c}\text { Dose of N kg } \\
\text { ha }^{-1}\end{array}$} & \multicolumn{4}{|c|}{ Biostimulant } & \multirow[b]{2}{*}{ Mean } \\
\hline & & $\begin{array}{c}\text { Without } \\
\text { biostimulant } \\
\text { (control) }\end{array}$ & Algex & Tytanit & Asahi SL & \\
\hline \multirow{3}{*}{1} & 0 & A $123.4 \mathrm{a}$ & A $160.5 \mathrm{~b}$ & A $151.7 \mathrm{~b}$ & A $196.7 \mathrm{c}$ & $158.1 \mathrm{~A}$ \\
\hline & 120 & B 105.6 a & A $171.6 \mathrm{~b}$ & A $142.1 \mathrm{c}$ & B $183.5 \mathrm{~d}$ & $150.7 \mathrm{~A}$ \\
\hline & 180 & B $100.1 \mathrm{a}$ & B $128.8 \mathrm{~b}$ & B $112.5 \mathrm{c}$ & C $154.7 \mathrm{~d}$ & $124.0 \mathrm{~B}$ \\
\hline \multirow{3}{*}{2} & 0 & A 88.8 a & A $135.6 \mathrm{~b}$ & A 140.2 b & A $163.2 \mathrm{c}$ & $132.0 \mathrm{~A}$ \\
\hline & 120 & B 101.9 a & B $111.0 \mathrm{~b}$ & A $136.5 \mathrm{c}$ & B $148.6 \mathrm{~d}$ & $124.5 \mathrm{~A}$ \\
\hline & 180 & AB $92.6 \mathrm{a}$ & B $114.2 b$ & B $121.9 \mathrm{bc}$ & C $129.6 \mathrm{c}$ & $114.6 \mathrm{~B}$ \\
\hline \multirow{3}{*}{3} & 0 & A 94.6 a & A $107.3 \mathrm{~b}$ & A $121.2 \mathrm{c}$ & A $112.2 \mathrm{~b}$ & $108.8 \mathrm{~A}$ \\
\hline & 120 & $\mathrm{AB} 88.3 \mathrm{a}$ & B 97.4 b & B $113.1 \mathrm{c}$ & A $108.3 \mathrm{c}$ & $101.8 \mathrm{~B}$ \\
\hline & 180 & B $85.3 \mathrm{a}$ & B $90.4 \mathrm{a}$ & B 114.8 b & A $103.9 \mathrm{c}$ & $98.6 \mathrm{~B}$ \\
\hline \multirow{3}{*}{ Mean } & 0 & A $102.3 \mathrm{a}$ & A $134.5 \mathrm{~b}$ & A $137.7 \mathrm{~b}$ & A $157.4 \mathrm{c}$ & $133.0 \mathrm{~A}$ \\
\hline & 120 & A 98.6 a & A $126.7 \mathrm{~b}$ & A 130.6 b & A $146.8 \mathrm{c}$ & $125.7 \mathrm{~A}$ \\
\hline & 180 & A $92.7 \mathrm{a}$ & B $111.1 \mathrm{~b}$ & B 116.4 b & B $129.4 \mathrm{c}$ & $112.4 \mathrm{~B}$ \\
\hline 1 & \multirow{3}{*}{ Mean } & A 109.7 a & A 153.6 b & A $135.4 \mathrm{c}$ & A $178.3 \mathrm{~d}$ & $144.3 \mathrm{~A}$ \\
\hline 2 & & B $94.4 \mathrm{a}$ & B $120.3 b$ & A 132.9 c & B $147.1 \mathrm{~d}$ & $123.7 \mathrm{~B}$ \\
\hline 3 & & C $89.4 \mathrm{a}$ & C 98.4 b & B 116.4 c & C $108.1 \mathrm{~d}$ & $103.1 \mathrm{C}$ \\
\hline \multicolumn{2}{|c|}{ Mean } & $97.8 \mathrm{a}$ & $124.1 \mathrm{~b}$ & $128.2 \mathrm{~b}$ & $144.5 \mathrm{c}$ & 123.7 \\
\hline
\end{tabular}

Different lower-case letters within the same line indicate significant differences. Different uppercase letters indicate that the values in the column for individual factors (Dose $\mathrm{N}$ and Cut) and their interaction differ significantly

Nitrogen applied at the rate of 120 and $180 \mathrm{~kg} \mathrm{ha}^{-1}$ significantly reduced soluble carbohydrates in Italian rye grass dry matter (by $21.4 \%$, on average), regardless of the remaining experimental factors, compared with control where no nitrogen had been applied, the finding having been reported in earlier works of the authors of this paper.

Increased nitrogen rates were followed by the decline in solouble carbohytrates in the test grass harvested in units treated with different biostimulants although most of the differences were statistically insignificant.

\section{Conclusions}

Regardless of biostimulant application and nitrogen regime, Italian rye grass yield quality and quantity differed significantly for individual cuts and in study years. The highest concentration of chlorophyll in Italian rye grass leaves and protein compounds in dry matter were determined in plants harvested with the third cut. Significantly the highest amount of soluble carbohydrates was determined in the dry matter of Italian rye grass harvested with the first cut. The results reported here indicate that biostimulants applied in the study contributed to similar yield performance of plants fertilised with a nitrogen rate which was by $60 \mathrm{~kg} \mathrm{ha}^{-1}$ lower, the highest increase in yield (by $42.2 \%$ ) being recorded for Algex-treated grass. This finding indicates that it is possible to reduce nitrogen rates without compromising the yield, which is beneficial for the 
environment. An application of biostimulants beneficially affected Italian rye grass yield quality as it was followed by a significant increase in chlorophyll content in leaves as well as protein compounds and soluble carbohydrates in the dry matter of the test grass. Of the three biostimulants, the best effects were observed for Asahi-treated plants in terms of the concentration of chlorophyll in leaves and soluble carbohydrates, and for Tytanit-treated plants as far as protein compounds were concerned. The nitrogen rate of 120 and $180 \mathrm{~kg} \mathrm{ha}^{-1}$ significantly increased Italian rye grass yields, chlorophyll content in plant leaves and protein compounds, the concentration of soluble carbohydrates being significantly lower in the dry matter of test plants. Treatment of Italian ryegrass grown for animal feed with the test biostimulants is reasonable because they contribute to an increase in plant dry matter yield, chlorophyll content, protein compounds and soluble carbohydrates at each nitrogen fertilisation level. It should also be stressed that yields harvested in biostimulant-treated units fertilised with $120 \mathrm{~kg} \mathrm{~N}^{-1}$ were higher compared with non-treated plots fertilised with $180 \mathrm{~kg} \mathrm{~N} \mathrm{ha}^{-1}$. Of the test biostimulants, Algex was superior in terms of yield-formation properties. The favourable results of the study reported here as well as the fact that the effect of biostimulants is species- or even cultivar-dependent are a stimulus to continue research into an application of biostimulants to other species of meadow plants.

Acknowledgments. The results of the research carried out under the research theme No. 340/S/13 were financed from the science grant granted by the Ministry of Science and Higher Education

\section{REFERENCES}

[1] Aydin, A., Kant, C., Turan, M. (2012): Humic acid application alleviate salinity stress of bean (Phaseolus vulgaris L.) plants decreasing membrane leakage. - African Journal of Agricultural Research 7: 1073-1086.

[2] Blackmer, T. M., Schepers, J. S. (1994): Techniques for monitoring crop nitrogen status in corn. - Commun. Soil Science and Plant Analysis 24: 2507-2516.

[3] Borowski, E., Blamowski, Z. K. (2009): The effects of triacontanol 'TRIA' and Asahi SL on the development and metabolic activity of sweet basil (Ocimum basilicum L.) plants treated with chilling. - Folia Horticulturae 21(1): 39-48. DOI: 10.2478/fhort-2013-0124.

[4] Brown, P., Saa, S. (2015): Biostimulants in agriculture. - Frontiers in Plant Science. doi.org/10.3389/fpls.2015.00671.

[5] Ciepiela, G. A., Godlewska, A. (2014): Changes in protein compounds and monosaccharides in selected grass species following an application of seaweed extract. Polish Journal and Environmental Study 23(1): 35-41.

[6] Ciepiela, G. A., Godlewska, A. (2015): The effect of the biostimulant Kelpak SL on Lolium perenne L. yield, protein and chlorophyll contents at different nitrogen levels. Agrochimica 59(2): 124-135.

[7] Cwalina-Ambroziak, B., Amarowicz, R. (2012): Effects of Biological and Fungicidal Environmental protection on chemical composition of tomato and red pepper fruits. Polish Journal of Environmental Study 21(4): 831-836.

[8] El-Miniawy, S. M., Ragab, M. E., Youssef, S. M., Metwally, A. A. (2014): Influence of foliar spraying of seaweed extract on growth, yield and quality of strawberry plants. Journal of Applied Sciences Research 10(2): 88-94.

[9] Godlewska, A., Ciepiela, G. A. (2016 a): The effect of the biostimulant Kelpak SL on the content of some microelements in two grass species. - Journal of Elementology 21(2): 373-381. doi.org/10.5601/jelem.2015.20.2.858. 
[10] Godlewska, A., Ciepiela, G. A. (2016b): The effect of growth regulator on dry matter yield and some chemical components in selected grass species and cultivars. - Soil Science and Plant Nutrition 62(3): 297-302. doi.org/10.1080/00380768.2016.1185741.

[11] Haider, M. W., Ayyub, C. H. M., Pervez, M. A., Asad, H. U., Manan, A., Raza, S. A., Ashraf, I. (2012): Impact of foliar application of seaweed extract on growth, yield and quality of potato (Solanum tuberosum L.). - Soil and Environment 31(2): 157-162.

[12] Haroun, S. A., Shukry, W. H., Abbas, M. A., Mowafy, A. M. (2011): Growth and physiological responses of Solanum lycopersicum to atonik and benzyl adenine under vernalized conditions. - Journal of Ecology and the Natural Environment 3(9): 319-331.

[13] Hidangmayum, A., Sharma, R. (2017): Effect of different concentrations of commercial seaweed liquid extract of Ascophyllum nodosum as a plant bio stimulant on growth, yield and biochemical constituents of onion (Allium cepa L.). - Journal of Pharmacognosy and Phytochemistry 6(4): 658-663.

[14] Jankowski, K., Ciepiela, G. A., Jodełka, J., Kolczarek, R. (2005): Grassland. - University of Podlasie Press, Siedlce, pp. 119-122 (in Polish).

[15] Khan, W., Rayorath, U. P., Subramanian, S., Jithesh, M. N., Rayorath, P., Hodges, D. M., Critchley, A. T., Craigie, J. S., Norrie, J., Prithiviraj, B. (2009): Seaweed extracts as biostimulants of plant growth and development. - Journal of Plant Growth Regulation 28: 386-399. https://doi.org/10.1007/s00344-009-9103-x.

[16] Kocira, A., Kocira, S., Stryjecka, M. (2015): Effect of Asahi SL application on common bean yield. - Agriculture and Agricultural Science Procedia 7: 103-107.

[17] Kocira, A., Świeca, M., Kocira, S., Złotek, U., Jakubczyk, A. (2016): Enhancement of yield, nutritional and nutraceutical properties of two common bean cultivars following the application of seaweed extract (Ecklonia maxima). - Saudi Journal of Biological Sciences 25: 563-571.

[18] Kocira, S., Kocira, A., Kornas, R., Koszel, M., Szmigielski, M., Krajewska, M., Szparaga, A., Krzysiak, Z. (2017): Effect of seaweed extract on yield and protein content of two common bean (Phaseolus vulgaris L.) cultivars. - Legume Research 41(4): 589593. https://doi: 10.18805/LR-383.

[19] Kováčik, P., Wiśniowska-Kielian, B., Smoleń, S. (2018): Effect of application of mgtytanit stimulator on winter wheat yielding and quantitative parameters of wheat straw and grain. - Journal of Elementology 23(2): 697-708. doi.org/10.5601/jelem.2017.22.2.1461.

[20] Lola-Luz, T., Hennequart, F., Gaffney, M. (2013): Enhancement of phenolic and flavonoids compounds in cabbage (Brassica oleraceae var italica) following application of commercial seaweed extracts of the brown seaweed, Ascophyllum nodosum. Agricultural and Food Science 22: 288-295.

[21] Michałek, W., Kocira, A., Findura, P., Szparaga, A., Kocira, S. (2018): The Influence of Biostimulant Asahi SL on the Photosynthetic Activity of Selected Cultivars of Phaseolus vulgaris L. - Middle Pomerania Scientific Society of The Environmental Protection 20: 1286-1301.

[22] Murawska, B., Gabrowska, M., Spychaj-Fabisiak, E., Wszelaczyńska, E., Chmielewski, J. (2017): Production and environmental aspects of the application of biostimulators Asahi SL, Kelpak SL and stimulator Tytanit with limited doses of nitrogen. Environmental Protection and Natural Resources 28(4): 10-15.

[23] Nerissa, A., Farrell, A., Ramsubhag, A., Jayaraman, J. (2016): The effect of Ascophyllum nodosum extract on the growth, yield and fruit quality of tomato grown under tropical conditions. - Journal of Applied Phycology 28: 1353-1362. doi.org/10.1007/s10811-0150608-3.

[24] Pacheco, A. C., Sobral, L. A., Gorni, P. H., Carvalho, M. E. A. (2019): Ascophyllum nodosum extract improves phenolic compound content and antioxidant activity medicinal and functional food plant Achillea millefolium L. - Australian Journal of Crop Science 13(03): 418-423. DOI:10.21475/ajcs.19.13.03.p1342. 
[25] Przybysz, A., Gawronska, H., Gajc-Wolska, J. (2014): Biological mode of action of a nitrophenolates-based biostimulant: case study. - Frontiers in Plant Science 5: 1-15. DOI: 10.3389/fpls.2014.00713.

[26] Reguraman, V., Abraham, L. S., Inbakandan, D., Thirugnanasambandam, R., Senthilvelan, T., Jabeen, S. K. A., Prakash, P. (2019): Influence of seaweed extracts on growth, phytochemical content and antioxidant capacity of cowpea (Vigna unguiculata $\mathrm{L}$. Walp). - Biocatalysis and Agricultural Biotechnology 17: 589-594.

[27] Radkowski, A. (2013): Leaf greenness (SPAD) index in timothy-grass seed plantation at different doses of titanium foliar fertilization. - Ecological Chemistry Engineering A 20(2): 167-174.

[28] Renuka, N., Guldhe, A., Prasanna, R., Singh, P., Bux, F. (2018): Microalgae as multifunctional options in modern agriculture: current trends, prospects and challenges. Biotechnology Advances 36: 1255-1273. doi.org/10.1016/j.biotechadv.2018.04.004.

[29] Sharma, H. S. S., Fleming, C., Selby, C. H., Rao, J. R., Martin, T. (2014): Plant biostimulants: a review on the processing of macroalgae and use of extracts for crop management to reduce abiotic and biotic stresses. - Journal of Applied Phycology 26: 465-490. http://dx.doi.org/10.1007/s10811-013-0101-9.

[30] Sultana, V., Ehteshamul-Haque, S., Ara, J., Athar, M. (2005): Comparative efficacy of brown, green and red seaweeds in the control of root infesting fungi and okra. International Journal of Environmental Science and Technology 2(2): 129-132. doi.org/10.1007/BF03325866.

[31] Systematics of Polish Soil (2011): Without title. - Annals of Soil Science 62(3): 1-193.

[32] Tuhy, Ł., Chowańska, J., Chojnacka, K. (2013): Seaweed extracts as biostimulants of plant growth: review. - Chemik 7(67): 636-641.

[33] Whitted-Haag, B., Kopsell, D. E., Kopsell, D. A., Rhykerd, R. L. (2014): Foliar silicon and titanium application influence growth and quality characteristics of annual bedding plants. - Open Horticulture Journal 7: 6-15. doi.org/10.2174/1874840601407010006.

[34] Zodape, S. T., Mukhopadhyay, S., Eswaran, K., Reddy, M. P., Chikara, J. (2010): Enhanced yield and nutritional quality in green gram (Phaseolus radiata L.) treated with seaweed (Kappaphycus alvarezii) extract. - Journal of Scientific and Industrial Research 69(6): 468-471. 